\title{
O Batismo de crianças adotadas por pessoas do mesmo sexo (Parte II) $^{1}$
}

\author{
The Baptism of children adopted by people of the same sex \\ (Part II)
}

\section{Marcio Fernando França ${ }^{2}$}

Resumo: A possibilidade de batizar crianças adotadas por pessoas do mesmo sexo, traz consigo algumas consequências no plano pastoral e litúrgico. A primeira delas, é o acompanhamento pastoral personalizado com o qual os responsáveis pelas crianças são ajudados a refletir sobre o sentido do seu pedido, instruídos quanto a celebração do sacramento e, ao mesmo tempo, auxiliados em sua tarefa de educar na fé. A responsabilidade pelo acompanhamento repousa sobre o pároco, que deve garanti-lo pessoalmente ou por meio de outros (catequistas e outros leigos idôneos). Além disso, é de suma importância a escolha dos padrinhos, sendo indispensável a estes preencher os requisitos determinados pelo Código para comprovar a aptidão ao ofício (cf. can. 874 §1), e a presença
Abstract: The possibility of baptizing adopted children by people of the same sex has some consequences in the pastoral and liturgical plan. The first of these is the personalized pastoral accompaniment with which those responsible for the children are helped to reflect on the meaning of their request, instructed in the celebration of the sacrament and, at the same time, helped in their task of educating in the faith. The responsibility for accompaniment rests with the parish priest, who must guarantee it personally or through others (catechists and other suitable lay people). Furthermore, the choice of sponsors is of the utmost importance, and it is indispensable for them to fulfill the requirements determined by the Code in order to prove their aptitude for the office (cf. can. 874

1 A primeira parte, que trata das razões que justificam a administração do Batismo à criança adotada por pessoas do mesmo sexo, encontra-se publicada em Scientia Canonica v.2, n. 4/2019-223-248.

2 Presbítero da Arquidiocese de Londrina - PR. Graduado em Filosofia pelo Instituto Filosófico de Apucarana - PR e Bacharel em Teologia pela Pontifícia Universidade Católica do Paraná (PUCPR). Mestre em Direito Canônico pelo Pontifício Instituto de Direito Canônico do Rio de Janeiro - Extensão Londrina - e Doutor em Direito Canônico pela Pontifícia Universidade Gregoriana de Roma Itália. E-mail: marcio.ffranca@hotmail.com 
da comunidade que acolhe a criança, a assiste no Batismo e colabora na sua educação cristã. Deve ainda o pároco agir de maneira prudente, cuidando que a celebração não seja instrumentalizada, a fins políticos ou de promoção da cultura gay, mas sim preparada convenientemente, com a devida dignidade, de modo piedoso e com exatidão, "segundo o ritual prescrito nos livros litúrgicos aprovados" (can. 850). Quanto ao modo de proceder a anotação no livro dos batizados, aplicar-se-á a normativa do can. 877 $\S \S 1-3$, com as devidas adaptações que o caso exige.

Palavras chave: Batismo de criança, acompanhamento pastoral, pároco, padrinhos, celebração, registro de Batismo.
$\S 1)$, and the presence of the community that welcomes the child, assists him in Baptism and collaborates in his Christian education. The pastor must also act prudently, taking care that the celebration is not used for political ends or for the promotion of gay culture, but is properly prepared, with due dignity, in a pious manner and with precision, "according to the ritual prescribed in the approved liturgical books" (can. 850). As to the manner of proceeding with the annotation in the book of the baptized, the norms of can. $877 \S \S 1-3$ will be applied, with the appropriate adaptations that the case requires.

Keywords: Baptism of a child, Pastoral accompaniment, Pastor, Godfathers, Celebration, Baptism Registration.

\section{Introdução}

O Batismo, cujo significado é mergulhar, imergir, é a porta pela qual se entra na Igreja (cf. $L G 14$ ). É o primeiro e fundamental sacramento no processo da iniciação cristã, que introduz plenamente o homem no mistério da salvação. Ao receber de Cristo a missão de anunciar o Evangelho e batizar (cf. Mt 28, 19; Mc 16, 15-16), a Igreja manteve-se fiel a esta ordem e batizou não só os adultos, capazes de um ato de fé explícito, mas também as crianças, entendendo que não devia privá-las deste sacramento para não negligenciar a missão recebida de fazer "nascer da água e do Espírito" $\left(J_{o} 3,5\right)$ todos aqueles que podem ser batizados.

Tendo tratado anteriormente das razões que justificam a administração do Batismo à criança adotada por pessoas do mesmo sexo, esta segunda parte do artigo se ocupará das questões práticas, à luz dos Direitos codicial e litúrgico. Após delinear a fisionomia do acompanhamento pastoral, prosseguem as questões conexas ao sacramento: a preparação dos adotantes pelo pároco, a escolha dos padrinhos e as exigências para o encargo, o auxílio da comunidade eclesial, a prepa- 
ração da celebração e o modo de registrar o Batismo no livro dos batizados.

\section{Acompanhamento pastoral de pessoas homossexuais}

Dentro dos princípios orientadores da revisão do novo Código, buscou-se "favorecer ao máximo a cura pastoral das almas"3. Sendo esta a arte de edificar o Corpo Místico de Cristo, "não se pode negar a necessidade de um esforço pastoral aprofundado e, sob certos aspectos, renovado"4 como forma de solucionar os problemas e desafios surgentes no contexto socioeclesial atual.

É um dever pastoral ir ao encontro daqueles que estão longe da fé ou da conduta evangélica. $O$ fato de viver em estado objetivo de pecado, não impede que uma pessoa dê testemunho da sua fé. O testemunho é uma exigência da condição batismal e não pode ser desqualificado porque a pessoa em uma determinada área de sua vida, não tenha uma atitude coerente com a fé professada.

A ação pastoral de acompanhamento de pessoas homossexuais "deve ter como objetivo ajudar cada um a construir o melhor possível, levando em conta sua orientação particular, suas relações humanas e sua vida com Deus" 5 . É de suma importância a acolhida fraterna e evangélica, "com respeito, compaixão e delicadeza"6. É preciso recebê-las com caridade, ajudando-as a esclarecer o estado concreto de sua condição, mediante um trabalho pastoral iluminado e iluminador. Não obstante, "não é e nem nunca deverá ser legítimo afirmar que os atos homossexuais são, por direito, atos [...] comparáveis em termos éticos com os heterossexuais"?.

Os casos particulares daqueles conviventes, civilmente ou não, que solicitam o sacramento do Batismo às crianças que estão sob seus cuidados, é necessário considerar dois grandes princípios apontados pela Instrução sobre o Batismo de crianças (20 out. 1980) da Congre-

3 Prefácio in Código de Direito canônico, 18.

4 SACRA CONGREGATIO PRO DOCTRINA FIDEI, Instructio De Baptismo parvulorum, 27.

5 A.D. Busso, «La parroquia, comunidad de caridad», 137.

6 Jỗo PaUlo II, Catecismo da Igreja Católica, 2358.

7 A.D. Busso, «La parroquia, comunidad de caridad», 136. 
gação para Doutrina da Fé: 1) "[o] Batismo, necessário para a salvação, é o sinal e o instrumento do amor preveniente de Deus, que liberta do pecado original e comunica a participação na vida divina: por si, o dom destes bens às criancinhas não deve ser diferido; [...] 2) [devese] estar na posse segura de garantias de que tal dom se possa desenvolver, mediante uma verdadeira educação na fé e na vida cristã, de modo que o Sacramento atinja a sua total "verdade"" .

Esses critérios devem ser entendidos como um indicativo dos objetivos orientadores da ação pastoral e não tanto como normas rígidas nas quais basear-se para admitir ou protelar a celebração do Batismo. Embora não sejam suficientes para elaborar todas as soluções práticas exigidas pela ação pastoral, esses princípios fornecem uma orientação geral com a qual os responsáveis pelas crianças sejam ajudados a refletir sobre o sentido do seu pedido e, ao mesmo tempo, auxiliados em sua tarefa de educar na fé.

São eles próprios os mais indicados para fornecerem ao sacerdote os elementos de juízo necessários para a realização do Batismo. Ninguém melhor do que eles para saber o que se quer quando solicitam o sacramento, o que este representa para eles e se estão dispostos a assumir os compromissos correspondentes. É preciso intuir as expectativas dos responsáveis sob os motivos por eles expressos e ajudálos a esclarecer a si próprios o sentido verdadeiro do seu pedido.

$\mathrm{O}$ fato de pedir o Batismo mostra que ainda possuem alguma ligação com a Igreja. Preferencialmente, procurarão o sacerdote que souber mostrar-se acolhedor e aberto aos seus problemas. Antes de qualquer decisão, para fundar uma verdadeira pastoral do Batismo de crianças adotadas por homossexuais, é necessário: a) acolher e estabelecer um diálogo respeitoso; b) discernir a qualidade de relação existente entre os conviventes e a comunidade local ${ }^{9}$; c) promover uma ação de acompanhamento.

8 SACRA CONGREGATIO PRO DoCTRINA FIDEI, Instructio De Baptismo parvulorum, 28.

9 "É necessário distinguir entre aquelas que fizeram uma escolha pessoal, muitas vezes atormentada, e que a vivem com delicadeza para não provocar escândalo, e um comportamento de promoção e publicidade concreta, frequentemente agressiva", SíNODO DOS BisPOS, Instrumentum laboris, 116. 
Esses passos contribuirão para um discernimento autêntico do pedido e incidirá sobre a preparação do sacramento e seu desenvolvimento. Embora em alguns lugares seja difícil colocar em prática, "não se devia aceitar nenhum batizado sem pedido prévio na própria paróquia"10. As proximidades humanas e geográficas, contribuiriam oportunamente "para uma investigação calma, para uma instrução ou, se for o caso, para uma evangelização mais prolongada" ${ }^{11}$, dos casos concretos que hão de surgir no seio da comunidade.

Esta etapa preparatória será, muitas vezes, a parte principal da pastoral. Para uma caminhada satisfatória que produza bons frutos requerer-se-á tempo, organização e dedicação. Ao término, o pároco dará o nihil obstat quanto ao batizado. Nesses casos, a comunidade que acolhe não se limitará em discernir se existe a "fundada esperança de que a criança será educada na religião católica” (can. 868 §1, 2º), mas agirá para tal fundamento acontecer.

\section{Preparação pelo pároco}

Os cann. $528 \S \S 1-2$ e $529 \S 1$, estabelecem os conteúdos gerais da função pastoral correspondentes ao pároco de acordo com o tríplice múnus - docendi, sanctificandi et regendi - adotado pelo Concílio Vaticano II na descrição da função ministerial da Igreja, enquanto o can. 530 prescreve as funções especialmente confiadas a ele.

É evidente que os deveres do pároco são múltiplos e não se esgotam nos cânones indicados. Destaca-se ainda no conjunto de deveres enumerados pelo Código como sendo necessários para a formação na fé e a santificação dos membros da comunidade paroquial, a preparação adequada "mediante devida evangelização e instrução catequética" (can. 843 §) daqueles solicitantes dos sacramentos.

Se o pedido for o Batismo para uma criança, a preparação diz respeito aos pais ou responsáveis e aos padrinhos, os quais deverão ser convenientemente instruídos sobre o significado desse sacramento e as obrigações anexas (cf. can. 851, $2^{\circ}$ ). A responsabilidade repousa sobre

10 J. SNOEK, «Os sacramentos da iniciação cristã», 155.

11 J. SNOEK, «Os sacramentos da iniciação cristã», 155. 
o pároco, que providenciará pessoalmente ou por meio de outros (catequistas e outros leigos idôneos) a devida instrução ${ }^{12}$.

Quanto aos responsáveis homossexuais, a instrução acontecerá por meio de um acompanhamento personalizado ${ }^{13}$, utilizando-se dos meios descritos no próprio Código: exortações pastorais, oração comunitária nos grupos de famílias e visitação, e outros determinados pelo Bispo diocesano ou pela Conferência Episcopal (cf. can. 851, $2^{\circ}$ ).

O encontro com essas pessoas oferecerá ao pároco e demais agentes de pastoral a oportunidade para propor a mensagem evangélica sem impor, anunciar de forma gradual o ensinamento da Igreja sobre o amor humano, o matrimônio, a família e a sexualidade, exortando-os com caridade a viver conforme o próprio Batismo ${ }^{14}$.

O pároco, como ministro da "caridade pastoral" ( $L G 41 ; P O 14)$, certificará se as motivações apresentadas são condizentes com a natureza do pedido e se as garantias exigidas para a futura educação na fé da criança a ser batizada serão cumpridas. Compete ao pároco, portanto, discernir cada caso em particular e aplicar a norma com justiça e equidade ${ }^{15}$.

Em todo caso, o discernimento inicial não será considerado um simples trâmite burocrático, mas um momento privilegiado de diálogo e aproximação com a Igreja, buscando evitar uma rígida severidade antievangélica ou uma excessiva debilidade ou condescendência, quando não houver esperança de perseverança no futuro ${ }^{16}$.

\section{A escolha dos padrinhos}

A instituição de padrinhos é uma antiquíssima tradição da Igreja (cf. can. $762 \S 1$, CIC 1917). Como representantes da comunidade cristã que acolhe o novo batizado, os padrinhos "ocupam um posto hono-

\footnotetext{
12 Cf. Observações preliminares, n. 13. In: Ritual do Batismo de crianças.

13 Cf. G.R. Millán, Orientaciones jurídico-pastorales, 9.

14 Cf. CONFERÊNCIA NACIONAL DOS BISPOS DO BRASIL, Orientações pastorais $e$ canônicas, 3; CONGREGAÇÃO PARA A EDUCAÇÃO CATÓLICA, Homem e mulher os criou, 30-38; G.R. MILlÁN, Orientaciones jurídico-pastorales, 9.

15 Cf. CONFERÊNCIA NACIONAL DOS BISPOS DO BRASIL, Orientações pastorais $e$ canônicas, 3.

16 Cf. J. SAN JosÉ PRISCO, Derecho parroquial, 208.
} 
rífico, embora muitas vezes humilde" ${ }^{\prime 17}$. Os cann. 872, 873 e $874 \S \S 1$ 2 regulamentam esta função e fazem referência às exigências a serem cumpridas por aqueles a desempenhar essa missão ${ }^{18}$.

O can. 872 determina que ao batizando, enquanto possível, seja dado um padrinho. Essa formulação inicial do cânon - quantum fieri potest - atenua a obrigatoriedade da norma. Apesar disso, na situação pastoral aqui tratada é indispensável a presença de "cristãos firmes, capazes e prontos a ajudar o novo batizado"19, como forma de garantir a administração do sacramento.

Tratando-se de uma criança, a função própria dos padrinhos é apresentá-la ao Batismo junto com os pais, ou por quem lhes faz as vezes, e assumir com eles o compromisso de ajudá-la a "crescer na fé, observar os mandamentos e viver na comunidade dos seguidores de Jesus" ${ }^{20}$. Assumindo semelhante obrigação, os padrinhos cooperam de modo que o batizado leve uma vida congruente com o Batismo e cumpra fielmente as obrigações inerentes ao mesmo (cf. cann. 774 §2; 872).

Embora seja costume admitir um padrinho e uma madrinha juntos, contudo, basta apenas uma pessoa e não é necessário ser do mesmo sexo da criança ${ }^{21}$. Frequentemente, os padrinhos são escolhidos antes do Batismo por razões de parentesco, amizade ou prestígio soci-

17 PIUS XII, Litterae Encyclicae Mystici Corporis Christi, 17.

18 Cf. Quaderni Di DiritTo ECCLESIale, ed., Codice di Diritto canonico commentato, 753.

19 JoÃo PAUlo II, Catecismo da Igreja Católica, 1225.

20 Ritual do Batismo de crianças, 33. "Uma criança não é capaz de um ato livre de fé: ainda não a pode confessar sozinha e, por isso mesmo, é confessada por seus pais e pelos padrinhos em nome dela", FRANCISCUS, Litterae Encyclicae Lumem Fidei, 43.

21 "El código anterior establecía que fuera un solo padrino y del mismo sexo del niño, con el fin de evitar la multiplicación del impedimento de parentesco espiritual (vc. 764*). Dado que este impedimento ha desaparecido de la legislación actual, la razón de haber mantenido la norma parece ser la de no multiplicar los padrinos para evitar la devaluación de un ministerio tan relevante (c. 873). Lo común entre nosotros es que sean dos y de sexo distinto, varón y mujer, para representar más completamente la 'paternidad espiritual' que ejercen los padrinos en nombre de la Iglesia. No se puede, por tanto, aceptar como padrinos a dos varones o a dos madrinas mujeres. Pero con uno sería suficiente, y no es necesario que sea del mismo sexo del niño”, J. SAN JosÉ PRISCO, Derecho parroquial, 216. 
al. Para evitar maiores dificuldades é indispensável que os pais ou responsáveis sejam instruídos sobre o verdadeiro sentido religioso do apadrinhamento, do testemunho cristão dos candidatos e do desejo sincero de garantir à criança padrinhos capazes de exercerem eficazmente sua missão.

Visto que pela sua própria natureza o Batismo infantil exige um catecumenato pós-batismal, é de suma importância escolher bem o padrinho e a madrinha, cumprindo os requisitos exigidos pela Igreja. Na medida do possível, ao menos um dos dois corresponda aos critérios indicados. Em última análise, caberá ao pároco discernir a idoneidade dos candidatos de acordo com as normas estabelecidas pelo Direito.

As condições prescritas para a admissão ao encargo de padrinho ou madrinha são enumeradas pelo can. $874 \S \S 1-2$. O CIC de 1917 fazia uma distinção entre as condições ad validitatem (cf. can. 765, CIC de 1917) e ad liceitatem (cf. can. 766, CIC de 1917). A nova legislação aboliu tal distinção, simplificando as normas que são agora só $a d$ liceitatem $^{22}$. No $§ 1$, os requisitos exigidos pelo legislador são os seguintes:

1. Seja designado pelo próprio batizando, por seus pais ou por quem lhes faz as vezes, ou, na falta deles, pelo próprio pároco ou ministro, $e$ tenha aptidão e intenção de cumprir esse encargo (can. $874 \S 1,1^{\circ}$ ).

A eleição do padrinho cabe ao próprio batizando, se for adulto; se for criança, compete aos pais ou quem faz as suas vezes; em última instância, ao pároco ou ministro. Para este encargo se exige que a pessoa escolhida possua aptidão e intenção de assumir este múnus. É preciso um conhecimento, ainda que seja básico, dos mistérios da fé que serão transmitidos ao afilhado.

2. Tenha completado dezesseis anos de idade, a não ser que outra idade tenha sido determinada pelo Bispo diocesano, ou pareça ao pároco ou ministro que se deva admitir uma exceção por justa causa (can. $874 \S 1,2^{\circ}$ ).

22 Cf. L. Chiappetta - F. CAtozzella - Al., ed., Il Codice di Diritto canonico 2, 112-113. 
A idade mínima de dezesseis anos completos se justifica para garantir que o padrinho tenha percorrido um caminho de fé suficiente, permitindo-o acompanhar adequadamente seu afilhado. Este critério manifesta que tampouco poderá exercer o encargo aqueles que carecem do uso de razão. Poderá dispensar deste requisito o Bispo diocesano, estabelecendo uma idade superior ou inferior, levando em conta as circunstâncias concretas da diocese; também o pároco ou o ministro, desde que pareça justa a causa pela qual se admite esta exceção.

3. Seja católico, confirmado, já tenha recebido o santíssimo sacramento da Eucaristia e leve uma vida de acordo com a fé e o encargo que vai assumir (can. $874 \S 1,3^{\circ}$ ).

O padrinho deve ser católico, ou seja, batizado na Igreja católica ou nela recebido depois do Batismo; portanto, não poderão exercer o ofício os não batizados, os excomungados ou inabilitados para tal, os que abandonaram a Igreja por um ato formal, nem os catecúmenos. É preciso que tenha completado a iniciação cristã, quer dizer, ter recebido os sacramentos da Confirmação e da Eucaristia.

Por uma causa justa, a Confirmação pode ser dispensada, pois não se trata de uma condição exigida para validade do ofício. Por fim, o padrinho deve levar uma vida congruente com a fé e a missão que irá assumir, pois se trata de um ministério que exige a plenitude do testemunho cristão.

4. Não se encontre atingido por nenhuma pena canônica legitimamente irrogada ou declarada (can. $874 \S 1,4^{\circ}$ ).

A pessoa escolhida não poderá estar ligada a nenhuma pena canônica legitimamente imposta ou declarada. Se a pena somente é conhecida no foro interno, não há impedimento para que o seja.

5. Não seja pai ou mãe do batizando (can. $874 \S 1,5^{\circ}$ ).

Obviamente, não ser o pai ou a mãe do batizando, uma vez que eles são, por lei natural, os primeiros responsáveis pela educação religiosa e moral dos seus filhos e nada acrescentaria a esta missão o fato de serem padrinhos. 
Dada a importância concedida a esta missão, concorde com as normas ecumênicas estabelecidas para os vários casos, o legislador, no $\S 2$ do mesmo cânon, assim estabelece: “[quem] é batizado e pertence a uma comunidade eclesial não-católica só seja admitido junto com um padrinho católico, e apenas como testemunha do batismo" (can. $874 \S 2)$.

Portanto, um cristão batizado pertencente a uma comunidade eclesial não católica pode ser admitido, ao lado do padrinho católico (ou madrinha católica), como testemunha do Batismo; consequentemente, não adquire os encargos e obrigações de padrinho. Todavia, os cristãos orientais que não estão em plena comunhão com a Igreja católica podem ser verdadeiramente padrinhos (ou madrinhas), junto com outro padrinho (ou madrinha) católico ${ }^{23}$.

Considerando a gravidade de educar as crianças na fé cristã, o encargo não poderá ser ocupado por qualquer pessoa nem ser facultativo no caso abordado. É indispensável ao candidato preencher os requisitos determinados pelo Código para comprovar sua aptidão ao ofício e, consequentemente, ser administrado o sacramento. Desta forma, a fundada esperança será atribuída aos padrinhos, caso os conviventes homossexuais não deem as garantias exigidas ${ }^{24}$.

\section{0 auxílio da comunidade eclesial}

O sacramento do Batismo incorpora o novo cristão à Igreja universal, "estabelecida por toda a terra" (SC 42). Mas é um fato que ela se torna visível nas comunidades locais, das quais a paróquia communitas christifidelium (cf. can. 515 §1) - é a mais comum. Nada mais natural e significativo, portanto, do que celebrar o Batismo na igreja paroquial, onde se reúne a comunidade cristã, que representa e faz parte da Igreja universal.

23 Cf. Observações preliminares, n. 10. In: Ritual do Batismo de crianças; CONFERÊNCIA NACIONAL DOS BISPOS DO BRASIL, Guia ecumênico, 45; can. $865 \S 3$, CCEO.

24 Cf. G.R. Millán, Orientaciones jurídico-pastorales, 8; J.F. FALCÃo DE BARROS, Os sacramentos da iniciação cristã 13. 
Segundo o Catecismo da Igreja Católica "a comunidade eclesial inteira tem uma parcela de responsabilidade no desenvolvimento e na conservação da graça recebida no batismo" 25 . Como toda a comunidade recebe a criança e a assiste no Batismo, assim também toda a comunidade é responsável pela sua educação cristã.

No rito batismal, após interrogar pais e padrinhos, quem preside pede à comunidade que manifeste seu compromisso de fé e vida cristã: "[e] todos vocês, queridos irmãos e irmãs aqui reunidos, querem ser uma comunidade de fé e de amor para estas crianças?"26; "[assim] se demonstra que a fé, em que são batizadas as crianças, não é somente da família, mas constitui um verdadeiro tesouro de toda a Igreja de Cristo"27.

Todo esforço desenvolvido por ocasião do Batismo deve ser inserido numa atividade pastoral mais abrangente que contemple, não somente a responsabilidade assumida pelos pais e padrinhos, mas de toda comunidade onde todos os novos membros são acolhidos na fé2 ${ }^{28}$. Atualmente, diante dos novos desafios, a presença da comunidade é um elemento que deve ganhar uma importância cada vez maior. A cada celebração do Batismo, todos são chamados a reafirmar sua fé em Deus e empenhar-se para proporcionar ao batizado um ambiente cristão.

É efetivamente da falta desse ambiente cristão que derivam todas as objeções contra o Batismo das crianças. Se os responsáveis, pessoalmente, não possuem as condições necessárias para educá-las na fé, é preciso suprir esta lacuna através dos padrinhos com o auxílio da comunidade que se compromete no desenvolvimento da graça batismal.

Dado que em todos os batizados a fé deve crescer após o Batismo, a responsabilidade da comunidade não se limita ao momento da celebração litúrgica, mas se prolonga no quotidiano do cristão por meio da formação dos próprios membros (catequese pós-batismal) e do acolhimento num ambiente onde possam viver plenamente aquilo

25 Jỗo PaUlo II, Catecismo da Igreja Católica, 1255.

26 Ritual do Batismo de crianças, 34.

27 Observações preliminares, n. 4. In: Ritual do Batismo de crianças.

28 Observações preliminares, n. 7. In: Ritual do Batismo de crianças. 
que aprenderam. Sem este compromisso, o sinal sacramental ficaria mutilado e a vida comunicada (graça) exposta a um aborto espiritual ${ }^{29}$.

\section{Da celebração do Batismo}

De acordo com as normas estabelecidas nos cann. 850-860 e nas Observações preliminares do Ritual do Batismo de crianças, a celebração deve ser preparada convenientemente. Uma celebração bem preparada contribui para uma frutuosa acolhida do dom de Deus. Os parágrafos seguintes apresentam algumas orientações para realização da cerimônia batismal de maneira eficaz e verdadeira.

Ao deferir o pedido do Batismo o pároco agirá de maneira prudente, cuidando da celebração para não ser interpretada como uma espécie de aprovação da união homossexual dos responsáveis solicitantes do sacramento à criança. Como em toda celebração sacramental, os ministros sagrados e os demais fiéis deverão ter uma atitude de suma veneração e devida diligência (cf. can. 840) ${ }^{30}$.

Quanto ao lugar, o Ritual estabelece a igreja paroquial como local ordinário da celebração, "para que apareça com maior clareza que o batismo é um sacramento de fé na Igreja e de agregação ao povo de Deus" 31 . Semelhantemente o Código determina, como regra geral, administrar o Batismo à criança na igreja paroquial dos pais, exceto se uma causa justa aconselhe outra coisa (cf. can. 857 §2).

A referência feita à igreja paroquial se justifica por ser o centro da iniciação à vida espiritual e sacramental dos fiéis, o lugar privilegiado para desenvolver uma pastoral batismal eficiente, onde os responsáveis pelas crianças recebem os meios adequados de preparação para o Batismo e garantem a continuidade do itinerário sacramental em suas vidas ${ }^{32}$.

Sempre que possível, o Batismo seja realizado em comum, sem nenhuma distinção. Como o Ritual prevê a presença dos pais, citando-

\footnotetext{
29 Cf. IoAnnes Paulus II, Adhortatio Apostolica Catechesi Tradendae, 24.

30 Cf. G.R. Millán, Orientaciones jurídico-pastorales, 9.

31 Observações preliminares, n. 10. In: Ritual do Batismo de crianças.

32 Cf. M. BLANCO, «Comentario al cann. 857-858», 467.
} 
os com frequência nas orações e exortações, o ministro poderá fazer as adaptações necessárias durante o rito ${ }^{33}$.

É preciso estar atento quanto à intenção daqueles que solicitam o sacramento. O pároco cuidará da celebração do Batismo para não ser instrumentalizada a fins políticos ou de promoção da cultura gay. Toda instrumentalização é uma falta grave a desvirtuar a verdadeira finalidade do sacramento e necessariamente deve ser refutada com o objetivo de não gerar confusão no Povo de Deus ${ }^{34}$.

Deve ainda o pároco empenhar-se para celebrar o Batismo com a devida dignidade, de modo piedoso e com exatidão, "segundo o ritual prescrito nos livros litúrgicos aprovados" (can. 850). Sem deixar de ser afável no trato com as pessoas, o pároco deixará claro que o sacramento se administra única e exclusivamente para o bem da criança $\mathrm{a}^{35}$.

\section{Do registro do Batismo}

Particular atenção deve ter o pároco ao registrar o Batismo de uma criança adotada por pessoas do mesmo sexo. Se os adotantes de algum modo, por si ou por outros, derem as garantias necessárias para educá-la na fé católica, o pároco procederá com o Batismo e o seu posterior registro. Resta apenas o problema de como registrar, quais os dados devem constar do livro dos batizados tendo em conta a opção sexual dos adotantes. Uma análise detalhada da legislação canônica contribuirá para uma correta interpretação da lei e elaboração do registro em questão.

O can. $877 \S \S 1-3$ apresenta o núcleo normativo referente ao registro do Batismo. Os parágrafos do cânon supracitado determinam o modo de proceder a anotação conforme os casos apresentados pelo legislador, a saber na sequência.

33 Cf. Observações preliminares, nn. 34-35. In: Ritual do Batismo de crianças.

34 Cf. G.R. Millán, Orientaciones jurídico-pastorales, 10.

35 Cf. G.R. Millán, Orientaciones jurídico-pastorales, 9. 


\subsection{Fixação dos dados do registro no livro dos batizados}

No tocante ao registro de Batismo, o Código determina que "[o] pároco do lugar em que se celebra o batismo deve registrar no livro dos batizados, cuidadosamente e sem nenhuma demora, os nomes dos batizados, fazendo menção do ministro, pais, padrinhos, bem como testemunhas, se as houver, do lugar e dia do batismo, indicando ao mesmo tempo o dia e o lugar do nascimento" (can. 877 §1).

Segundo as disposições do $§ 1$, a pessoa sobre a qual recai a obrigação de registrar é o pároco do lugar em que se celebra o Batismo, ao contrário do que estabelecia o can. $777 \S 1$ do CIC 1917. O legislador emprega as expressões sedulo et sine ulla mora ao registro a fazer menção: do nome do batizado, do ministro, dos pais e dos padrinhos, bem como de eventual testemunha, se houver (cf. can. 874 §2), do lugar e dia do Batismo e dia e lugar do nascimento.

\subsection{Caso de filhos de mãe não-casada}

O registro em caso de filhos de mãe não-casada, o legislador estabelece no §2: "[tratando-se] de filhos de mãe não-casada, deve-se consignar o nome da mãe, se consta publicamente sua maternidade ou ela o pede espontaneamente por escrito perante duas testemunhas; deve-se também inscrever o nome do pai, se sua paternidade se comprova por algum documento público ou por declaração dele, feita perante o pároco e duas testemunhas; nos outros casos, inscreva-se o que foi batizado, sem fazer nenhuma indicação do nome do pai ou dos pais" (can. 877 §2).

A normativa prevê no caso de uma criança de mãe não-casada a realização do registro da seguinte maneira: a) registro do nome da mãe: se consta publicamente a sua maternidade ou ela o peça de forma espontânea por escrito perante duas testemunhas; b) registro do nome do pai: se sua paternidade se comprova por meio de documento público ou por declaração dele, feita perante o pároco e duas testemunhas; c) registro apenas do nome do batizado: nos outros casos, quando não se sabe quem é o pai, registra-se somente o nome da mãe e vice-versa. 
Quando não se sabe quem é o pai e nem a mãe, registra-se sem os seus nomes.

Nota-se a previsão legislativa da possibilidade de registrar apenas o nome do batizado quando não se sabe quem são os seus pais. Portanto, o campo reservado para anotar o nome do pai e da mãe no livro dos batizados ficará em branco, sem constar nada.

\subsection{Caso de filho adotivo}

Para o caso de filho adotivo, o $\S 3$ determina: "[tratando-se] de filho adotivo, inscrevam-se os nomes dos adotantes, como, também, ao menos se assim se faz no registro civil da região, os dos pais naturais, de acordo com os $\S \S 1-2$, atendendo às prescrições da Conferência dos Bispos" (can. 877 §3). Quando se trata de filhos adotivos, o registro deve conter: a) o nome dos adotantes; b) o nome dos pais biológicos se consta no registro civil, nos termos dos $\S \S 1-2$, de acordo com as disposições da Conferência Episcopal ${ }^{36}$.

Diante desta referência é importante observar a diferença redacional existente entre os três parágrafos. Nos dois primeiros o legislador usa os termos latinos parentibus, matris, patris, parentum para designar aqueles que exercem a paternidade e maternidade, ou seja, um homem e uma mulher. Já o terceiro parágrafo usa as expressões nomina adoptantium e parentum naturalium: aqui o legislador só chama de pais os pais naturais (parentum naturalium), mas não os adotantes ${ }^{37}$.

Quando a Igreja faz uso dos termos família, pais, pai, mãe e filhos em um sentido próprio e estrito, adota como ratio da norma o Direito natural fundado no fato da geração (vínculo biológico). Já a ado-

36 A Conferência Nacional dos Bispos do Brasil (CNBB), quanto ao can. 877 §3, estabeleceu na Legislação Complementar ao Código de Direito Canônico o que segue: "Na inscrição dos filhos adotivos, constará não só o nome do adotante, mas também o dos pais naturais, sempre que assim conste do registro civil", CONFERÊNCIA NACIONAL DOS BISPOS DO BRASIL, «Apêndice», 422.

37 Cf. CONFERÊNCIA NACIONAL DOS BISPOS DO BRASIL, Orientações pastorais e canônicas, 5. 
ção se refere a um tipo de vínculo que é de ordem legal, mas não natu$\mathrm{ral}^{38}$.

Como a adoção deve imitar a natureza - adoptio imitat natu$\mathrm{ram}^{39}$-, entende-se que "os filhos que foram adotados de acordo com a lei civil são considerados filhos daquele ou daqueles que os adotaram" (can. 110). Portanto, se justifica inscrever no livro dos batizados o nome dos adotantes como pais dos adotados segundo as determinações do can. $877 \S \S 1-2$. Todavia, no caso de crianças adotadas por pessoas do mesmo sexo, não se observa a natureza das coisas. Sendo assim, como ficaria o registro? É o que se verá na sequência.

\subsection{Caso de crianças adotadas por pessoas do mesmo sexo}

Como consequência das mudanças sociais e legislativas civis nas últimas décadas, surgiram "novas modalidades de família", ampliando aquilo que se entende originalmente por família, pais, pai, mãe e filhos. O legislador, ao reconhecer as uniões homoafetivas como entidade familiar, relativizou o dado biológico colocando-o no mesmo plano de outros critérios. Tais mudanças, além de induzir ao erro, causam graves dificuldades à vida eclesial ${ }^{40}$.

Também é claro que o estabelecimento, via adoção, de vínculos de paternidade-maternidade e filiação entre um menor e dois homens ou duas mulheres são contrário ao Direito divino natural. Por ser essencialmente inalterável, o Direito divino tem a função de limite, introduzida pelo legislador no ordenamento canônico positivado, o que impossibilita a canonização da lei civil, ou seja, que "as leis civis, às quais o Direito da Igreja remete, sejam observadas no Direito canônico com os mesmos efeitos" (can. 22). Portanto, também não será lícito adotar a terminologia utilizada pelo Direito civil quando contrária ao Direito divino ${ }^{41}$.

38 Cf. CONFERÊNCIA NACIONAL DOS BISPOS DO BRASIL, Orientações pastorais $e$ canônicas, 5-6.

39 Cf. A. Polaino-Lorente, «"Matrimônio" de homossexuais», 620.

40 Cf. CONFERÊNCIA Nacional Dos Bispos Do Brasil, Orientações pastorais e canônicas, 6.

41 Cf. Cf. CONFERÊnCIA NACIONAL dos BISPOS Do BRAsil, Orientações pastorais e canônicas, 6; J.F. FALCÃO DE BARROS, Os sacramentos da iniciação cristã, 14. 
Considerando o exposto é preciso encontrar uma fórmula satisfatória para registrar o Batismo de crianças adotadas por pessoas do mesmo sexo, que se ajuste ao Direito divino, como um princípio básico de coerência. No referente às diferenças entre os ordenamentos civil e o canônico é preciso considerar três questões, como segue.

\subsubsection{O registro dos dados gerais no livro dos batizados}

Aplica-se o can. $877 \S 1$, registrando apenas o nome da criança, do ministro, dos padrinhos, das testemunhas, se as houver, do lugar e dia do Batismo e do nascimento.

\subsubsection{Se um dos pares for pai ou mãe natural e o outro for adotante}

Aplica-se o can. $877 \S 2$, registrando como pai, apenas o pai biológico; como mãe, a mãe biológica. A outra pessoa constará unicamente como adotante.

6.4.3 Se os dois homens ou as duas mulheres são adotantes

Aplica-se o can. $877 \S 3$, que determina inscrever: 1) os nomes dos adotantes; 2) também, os nomes dos pais naturais, se assim se faz no registro civil da região, atendendo às prescrições da Conferência dos Bispos ${ }^{42}$.

Em relação aos pontos 6.4 .2 e 6.4.3, a observância do documento civil só vale para o registro dos nomes dos pais naturais e não para os nomes dos adotantes do mesmo sexo. Sempre que constar os nomes dos pais naturais na certidão de nascimento da criança, tais nomes também serão inseridos no registro do Batismo. Do contrário, não aparecerá os nomes dos pais naturais ${ }^{43}$. É preciso recordar, também, o quanto estabelece a Conferência dos Bispos a este respeito ${ }^{44}$.

42 Cf. CONFERÊnCIA NACIONAL dos Bispos Do BRAsil, Orientações pastorais e canônicas, 6.

43 Cf. Cf. Conferência Nacional dos Bispos do Brasil, Orientações pastorais e canônicas, 6 .

44 Ver: CONFERÊNCIA NACIONAL DOS BisPos Do BRASIL, «Apêndice», 422. 
Independentemente de como apareça no registro civil, o pároco jamais inscreverá no campo reservado para anotar os nomes dos pais naturais do livro dos batizados, os nomes dos adotantes unidos por uma relação contrária ao Direito natural: "[o] que está claro é que sob nenhuma circunstância o nome de dois pais ou duas mães do mesmo sexo deve ser inscrito no livro de Batismos, pois é impossivelmente humano e um registro manifestamente impreciso, contraria a natureza das coisas" $"$.

Por fim, uma nota marginal no assento correspondente do livro dos batizados advertirá sobre a adoção (cf. can. 535 §2). Do mesmo modo, propomos acrescer à margem do livro, os nomes dos adotantes, para maior clareza e evidência do estado canônico da criança batizada: trata-se de um fiel adotado por pessoas do mesmo sexo. Logo, na margem do registro do Batismo da criança deverá constar, conforme o caso, as seguintes expressões: a) adotante: o nome do parceiro adotante; b) adotantes: os nomes dos dois homens ou das duas mulheres adotantes ${ }^{46}$.

Assim, se na margem do registro constar o nome de duas pessoas do mesmo sexo, subentende-se serem adotantes homoafetivos, independente dos nomes dos pais biológicos estarem registrados ou não; ou se constar apenas o nome de um dos pais biológicos (pai ou mãe) e à margem o nome de outra pessoa do mesmo sexo do pai ou da mãe, subentende-se haver uma relação homoafetiva.

Convém recordar, ainda, o dever de não fazer qualquer referência à paternidade ou maternidade reconhecida pelo Estado. Considerando que as anotações serão referidas na certidão de Batismo, para evitar dúvidas e possíveis conflitos, o pároco poderá explicar aos adotantes o porquê das diferenças de terminologia entre os registros civil e eclesiástico ${ }^{47}$.

45 J. SAN JOSÉ PRISCO, Derecho parroquial, 221.

46 Cf. J.F. FAlCÃo DE BARROS, Os sacramentos da iniciação cristã, 14.

47 Cf. CONFERÊnCIA NACIONAL DOS BISPOS DO BRASIL, Orientações pastorais $e$ canônicas, 7. 


\section{Conclusão}

Não obstante a complexidade do tema, vimos que é possível batizar as crianças adotadas legalmente por pessoas do mesmo sexo, desde que haja uma fundada esperança de que elas serão educadas na religião católica. Era necessário, portanto, apresentar algumas diretrizes pastorais e litúrgicas, para complementar a proposição anterior $\left(1^{\mathrm{a}}\right.$ parte).

É importante sublinhar que estas notas simples "não trouxeram nada de novo: nenhuma doutrina nova, nenhuma afirmação surpreendente, nenhuma proposta revolucionária, nenhuma orientação inédita"48. Apenas expuseram os pontos essenciais da doutrina da Igreja e sua prática constante, aplicadas a nova realidade dos adotados por pares homoafetivos.

Em suma, a promoção de uma pastoral batismal adequada em favor de crianças adotadas por pessoas do mesmo sexo requer o envolvimento de toda a comunidade eclesial, através de uma presença significativa e efetiva, e não somente do padre, dos pais e padrinhos. Espera-se dos membros um comprometimento verdadeiro, que assumam suas responsabilidades e contribuam, através do Batismo das crianças e de sua educação cristã, para o crescimento da Igreja, o Corpo de Cristo.

\section{Bibliografia}

\section{Papas}

PIUS XII, Litt. Encycl. Mystici Corporis Christi, 19 iun. 1943, AAS 43 (1943) 193-248.

IoAnNes Paulus II, Adhortatio Apostolica Catechesi Tradendae, 16 oct. 1979, AAS 71 (1979) 1277-1340.

Jỗo Paulo II, Catecismo da Igreja Católica. Novíssima edição de acordo com o texto em latim, $4^{\mathrm{a}}$ ed., São Paulo: Loyola 2017.

48 J.F. FALCÃo DE BARROS, Os sacramentos da iniciação cristã, 22. 
Franciscus, Litterae Encyclicae Lumem Fidei, 29 iun. 2013, AAS 105 (2013) 555-596.

\section{Concílios, Congregações, Conselhos, Conferências}

CONFERÊNCIA NACIONAL DOS BisPos do BRASIL, «Apêndice. Legislação complementar ao Código de Direito Canônico», in Código de Direito Canônico. Com a legislação complementar da CNBB, São Paulo $2013^{12}, 417-426$.

— Guia ecumênico. Informações, normas e diretrizes sobre Ecumenismo, Estudos da CNBB 21, 3ª ed., São Paulo: Paulus, 2003.

— Orientações pastorais e canônicas sobre o Batismo de crianças, filhas ou adotadas, por pessoas em união homossexual, Brasília: [S.n.], 2016.

CONGREGAÇÃO PARA A EDUCAÇÃO CATÓLICA, Homem e mulher os criou. Para uma via de diálogo sobre a questão do gender na educação, Coleção Documentos da Igreja 51, São Paulo: Paulinas, 2019.

Sacra Congregatio pro Doctrina Fidei, Instructio De Baptismo parvulorum, 20 oct. 1980, AAS 72 (1980) 1137-1156.

Sacrosantum Concilium Oecumenicum Vaticanum II, Const. de Sacra Liturgia Sacrosactum Concilium, 4 dec. 1963, AAS 56 (1964) 97-138.

SíNODO DOS BISPOS, Instrumentum laboris. Os desafios pastorais da família no contexto da evangelização, São Paulo: Paulinas, 2014.

\section{Livros e artigos}

BLANCO, M., «Comentario al cann. 857-858», in Á. MARZOA - J. MIRAS - R. RodríGUEZ-OCAÑA, ed., Comentario exegético al Código de Derecho Canónico, III/1, Navarra 2002³ , 466-468.

BuSSO, A.D., «La parroquia, comunidad de caridad», in FACULTAD DE Derecho Canónico, Pastores y fieles. Constructores de la comuni- 
dad paroquial, 9, Buenos Aires: Ediciones de la Universidad Católica Argentina, 1999.

FALCÃo DE BARROS, J.F., Os sacramentos da Iniciação cristã administrados aos adotados por pessoas do mesmo sexo que vivem em união estável. [S.i]; [S.n].

Millán, G.R., Orientaciones jurídico-pastorales sobre la admisión al Bautismo de los hijos, biológicos o adoptados, de parejas homosexuales. Diócesis de Osma-Soria.

Polaino-Lorente, A., "“Matrimônio" de homossexuais», in PONTIFÍCIO CONSELHO PARA A FAMÍliA, Lexicon. Termos ambíguos e discutidos sobre família, vida e questões éticas, Brasília: CNBB, 2007, 609-621.

Ritual do Batismo de crianças. Ritual Romano. Renovado por decreto do Concílio Vaticano II, promulgado por autoridade do Papa Paulo VI, São Paulo: Paulus, 2003.

SAN José PRISCO, J., Derecho parroquial. Guía canónica y pastoral, Salamanca: Ediciones Sígueme, 2008.

SNOEK, J., «Os sacramentos da iniciação cristã e o processo de descristianização», Revista Eclesiástica Brasileira 24 (1964) 151-157. 